2014-06-02

Tracing the impact of market reform on productivity growth of rice at the farm level in Bangladesh

\author{
Alam, MJ \\ http://hdl.handle.net/10026.1/3996
}

10.1080/13547860.2014.908533

Journal of the Asia Pacific Economy

Taylor \& Francis

All content in PEARL is protected by copyright law. Author manuscripts are made available in accordance with publisher policies. Please cite only the published version using the details provided on the item record or document. In the absence of an open licence (e.g. Creative Commons), permissions for further reuse of content should be sought from the publisher or author. 


\title{
Tracing the Impact of Market Reform on Productivity Growth of Rice at the Farm- Level in Bangladesh
}

\begin{abstract}
The paper measures the total factor productivity (TFP), technical change (TC), and technical efficiency change (TEC) in rice production and traces the impact of market reform policies of the 1990s on these indices at the farm level in Bangladesh using a unique cohort of three-period panel data $(1987,2000$ and 2004) of 73 farms by applying stochastic production frontier approach. Results reveal that the TFP index has increased by $27 \%$ largely due to an upward shift of the technology frontier. Although TC has increased by an impressive $57 \%$, TEC declined by $30.1 \%$ during the post reform period, thereby, depressing overall TFP growth. The market liberalization policies exerted significantly positive impacts on TC and TFP growth but negatively on TEC. Farm size and household size also significantly improved these indices while education, tenancy and off-farm income exerted negative effects. Policy implications include continued liberalization of markets and land reform measures to increase farm size.
\end{abstract}

Key words: TFP growth, technical efficiency change, technical change, market reform policies, farm-level, Bangladesh

JEL codes: D24, Q18, Q12 


\section{Introduction}

The government of Bangladesh has undertaken a range of direct and indirect policy interventions to develop the agricultural sector. During the 1970 s and 1980s, the agricultural policies were mainly state controlled and this did not seem to have worked as the country has observed a very low growth in technological progress (Selim, 2007). To overcome the stagnant situation in the economy in which agriculture plays a major role, the government has shifted all its policies gradually from state controlled mechanisms to market oriented approaches following the recommendations from the World Bank and the International Monetary Fund under its 'structural adjustment programme' (Salim and Hossain, 2006). A summary of the policies which evolved over the pre- (1977-1989) and post-market reform (1990-2004) periods are presented in Table 1. The reform policies started in the 1980s but the pace has increased in the 1990s. In the light of a failing system of input subsidies and output price support, the aims of the policy reforms were to increase production growth by reducing subsidies and price support, reorganizing the public food distribution system and realigning market incentives. All of the policy tools were synchronized to free up the domestic markets, thereby, encouraging import of inputs and outputs by allowing private sectors to be involved in the process. As a consequence, the role of the Bangladesh Agricultural Development Corporation was drastically reduced which was largely responsible for input procurement and distribution in the country. The government also reduced control in the agricultural input and output markets and lowered tariff and non-tariff barriers. It further gradually eliminated subsidies on fertilizer and minor irrigation equipments, minimized government involvement in input distribution, and allowed the private sector to distribute agricultural inputs. However, although various polices have been implemented gradually (after 1990s to till date) with the aim of increasing rice production and to improve long-term food security, the country is still identified as a food deficit country with occasional self-sufficiency in one or two years. 
As one of the most densely populated countries of the world with 140 million people, Bangladesh needs to feed an extra two million people every year (BBS, 2010). Although overall rice production steadily increased over the years (Hossain et al., 2005, FPMU, 2012), this is not yet sufficient to meet the demand of the growing population. The recently projected climate change effect on the agricultural production (mainly rice) in Bangladesh is alarming. Because of the effect of climate change via sea level rise, soil salination and reduced supply of the agricultural land, a recent study (Winston et al., 2010). estimated that rice production will decrease at an average rate of $7.4 \%$ per annum during the period $2005-$ 2050. Therefore, given the challenge to meet the emerging demand for rice because of the population growth and rising income on one hand, and projected decline in rice production due to climate change on the other, the policy makers of Bangladesh have accorded serious attention to food security.

Although the use of modern inputs in Bangladesh is still less than the global average, increasing its use is not a viable option in the long run mainly due to limited availability of crop land and the diminishing nature of input-driven growth. Therefore, the strategy for increasing output should rely on progress in technology and efficiency in the coming decades if agricultural supply is to keep up with growing demand for food (Rahman, 2007). The issue becomes more important in the light of projected decline in rice productivity due to the adverse effect of climate change in the coming years. Improvement in agricultural productivity is a fundamental pre-condition for sustainable economic development because it allows resources such as labour and capital to be diverted to expand the non-agricultural sector of an economy (O`Donnell, 2010). Total Factor Productivity (TFP) indices capture the effect of improvements in technology as well as investments in infrastructure such as irrigation, roads and electricity, in the form of research and development (Mukherjee and Kuroda, 2003). Growth in TFP is desirable as it not only implies higher output from application of technology and better utilization of resources, but also leads to a reduction in 
poverty in rural areas (Fan et al., 2000), another major policy objective of the Bangladesh government.

Given this backdrop, the main objectives of this study are: (a) to estimate the rate of TFP growth and its two main components (technical change and technical efficiency change) in rice production at the farm-level over time (1987-2004); and (b) to identify the impact of market reforms as wells as other socio-economic factors on TFP growth and its components at the farm-level during the same period.

$<$ Table 1 near here $>$

Studies on total factor productivity (TFP) and efficiency growth in Bangladesh agriculture are limited to the works of Coelli et al. (2003), Salim and Hossain (2006), Rahman (2007), and Rahman and Salim (2013). However, to our knowledge, no studies were conducted to estimate TFP growth and its components at the farm level in Bangladesh using panel data. Our contribution to the existing literature are two-fold: first, to provide an estimate of TFP growth, technical efficiency change (TEC) and technical change (TC) over time at the farmlevel by using a cohort of the samples that covers the pre- and post market reforms periods, and second, to trace the impact of the market policy reforms on TFP growth and its components at the farm-level. Since the major policy changes in relation to agriculture in general, and to rice crop in particular, have been introduced in the early 1990s, our analysis covers the periods of pre- and post-market reforms as we are using a unique cohort of 73 farms surveyed in 1987, 2000 and 2004 .

The remainder of the paper is organized as follows. Section 2 outlines the methodology. Section 3 describes the data, sampling procedures and the derivation of farm level panel data used for the analysis from a nationally representative data set. Section 4 presents various hypotheses tests conducted. The final section presents the results, concludes and draws policy implications.

\section{The analytical framework}


There are two competing approaches in the literature to measure efficiency, the nonparametric data envelopment analysis (DEA) and the parametric stochastic frontier analysis (SFA). The SFA has contributed significantly to the econometric modeling of production and efficiency. The SFA is a regression-based approach which assumes two unobserved error terms representing efficiency and statistical noise and allows the estimation of error terms via the methods of maximum likelihood. The advantage of SFA is the capability to measure efficiency in the presence of statistical noise. Many researchers (e.g., Ruggiero, 1999; Ondrich and Ruggiero, 2001) have explained the pros and cons of both the SFA and the DEA. Although both approaches are adversely affected by measurement error when applied to cross sectional data, the SFA with the panel data can effectively handle the statistical noise better than DEA. Gong and Sickles (1992) and Sickles (2005) show that the panel data version of the SFA works well in achieving relatively high rank correlations between estimated and true inefficiency. This is because the panel data model incorporates additional information from the time series nature of the data as well as the distributional assumptions and, therefore, maintains an advantage over DEA. Since we are using panel data in this study, we have chosen SFA with a simple exponential specification of timevarying farm effects using a cohort sample of 73 farms over time (1987, 2000 and 2004) periods.

The stochastic frontier production function for panel data can be written as:

$$
Y_{i t}=\exp \left(X_{n i t} \beta+V_{i t}-U_{i t}\right)
$$

where the dependent variable $Y_{i t}$ represents total rice production (kilogram/farm) by i-th farm in $\mathrm{t}$-th year (here, $\mathrm{t}=1,2,3$ in which 1 is for the year 1987; 2 is for the year 2000 and 3 for the year 2004), $X_{\text {nit }}$ denotes n-th input variables, $\beta$ is the associate vector of unknown parameters to be estimated; the statistical noise $V_{i t}$ are the error components which are assumed to be i. i. d (identically and independently distributed) with $\left\{\mathrm{N}\left(0, \sigma_{\mathrm{v}}{ }^{2}\right)\right\}$. The other 
error components $U_{i t}$ are non-negative random variables, associated with technical inefficiency in production, which are assumed to be i. i. $d$ with mean $\mu$ and variance $\sigma_{u^{2}}$ as well as truncated at zero. Since $U_{i t}$ is a non-negative random variable, these technical efficiency predictions are between zero and one, where the value of 1 indicates full technical efficiency and value of zero full technical inefficiency.

To calculate the TFP index between period $s$ (base period) and period $t$ (present period) we need to measure technical efficiency change (TEC) and technical change (TC). This TFP index is equivalent to the decomposition of the Malmquist index suggested by Fare et al., (1985). The technical efficiency for i-th farms at t-th years can be calculated using equation (2) as follows (Coelli et al., 2005):

$$
T E_{i t}=E\left[\exp \left(-U_{i t}\right) /\left(V_{i t}-U_{i t}\right)\right]
$$

TE change $\left(\mathrm{TEC}_{\mathrm{it}}\right)$ is then calculated as:

$$
T E C_{i t}=\frac{T E_{i t}}{T E_{i s}}
$$

Following Coelli et al., (2003) the index of technical change $\left(T C_{i t}\right)$ can be directly calculated between two adjacent period $s$ and $t$ from the estimated parameters of frontier model. The partial derivatives are evaluated with respect to time at $X_{i t}$ and $X_{i s}$. Then these are converted into indices and their geometric means are calculated. Following Coelli et al., (1998) the calculation of the technical change (TC) index is as follows in equation (4):

$$
T C_{i t}=\left\{\left[1+\frac{\delta f\left(X_{i s}, s, \beta\right)}{\delta S}\right] x\left[1+\frac{\delta f\left(X_{i t}, s, \beta\right)}{\delta S}\right]\right\}^{0.5}
$$

The indices of technical efficiency change $\left(T E C_{i t}\right)$ and technical change $\left(T C_{i t}\right)$ obtained by using equations (3) and (4) respectively can be multiplied with each other to obtain a TFP changes as follows in equation (5)

$$
T F P_{i t}=T E C_{i t} * T C_{i t}
$$




\section{Data and sampling}

The data for this paper are drawn from a longitudinal survey of 1239 households, beginning in 1987-88 with the support of the Bangladesh Institute of Development Studies (BIDS) to study the impact of technological progress on income distribution and poverty in Bangladesh (Hossain et al., 1994; David and Otsuka, 1994). At first, in this field survey 64 unions (smallest administrative unit) were randomly selected from a list of all unions (4486) in the country, then in the second stage, one village was selected from each union that represent the union best but on the basis of literacy rate and the land holding size. A census of all the households in the selected villages was compiled to stratify the households by the size of land ownership and land tenure. A random sample of 20 households was drawn from each village such that each stratum is represented by its probability proportion. A repeat survey was made by the International Rice Research Institute (IRRI) to the same villages in 2000-2001 for a study on the impact of rice research on poverty reduction in Bangladesh sponsored by the International Food Policy Research Institute (IFPRI). A sample of 30 to 31 households from each of the 62 villages (hence in total 1880 households) was drawn using the stratified random sampling method. The stratification was based on a wealth ranking technique of the participatory rural appraisal method. The third survey was made in 2004-05 by IRRI that covered the same households in the first two surveys in 1987-88 and 2000-01. The sample size of the households rose to 1927 in the third and last survey. The sample of these surveys is nationally representative (Rahman and Hossain, 1995; Hossain et al., 1994). However, given the objective of our study, we intended to use farm level panel data. Therefore we selected the same farm households who were included in all the three surveys, so that we get a balanced panel data for a cohort of farm households. Therefore, this panel data study at farm level will allow us to examine TFP growth in rice production and its components TEC and TC over a 17 year covering pre-reform (1987-88 survey) and postreform (2000-01 and 2004 surveys) periods. The total observation is 219 (i.e., 73 farms x 3 
years). These cover 27 villages from 26 districts. Though the size of sample is small, the cohort of farm-households is very unique and rarely available at farm-level that covers such a long time period of about two decades especially in a developing country like Bangladesh. Because we had to find a cohort of farm-households over these three surveys to fulfill our objectives, the sample size turned out to be smaller than we wished.

The following variables are used:

1. Output of rice: includes all seasons and all rice varieties (in kilogram (kg))

2. Inputs used for rice cultivation:
a. Land - total rice cultivated land (in decimal)
b. Seed- total amount of seed (in $\mathrm{kg}$ )
c. Labour:

i. Family labour-total man-days

ii. Hired labour-total man-days

d. Fertilizer-total amount of fertilizers (urea, phosphate, potash, and gypsum) in $\mathrm{kg}$

e. Pesticide-total value of pesticide (at 1996 constant prices)

Table 2 presents the definitions, units of measurement, and summary statistics for all the variables. Draft animal power is the main source of power used in Bangladesh agriculture, particularly during the period covered in the study. However, we did not use information on animal power because the information is incomplete in the surveys. Also, the rate of application of draft animal power mainly for land preparation function is largely fixed in nature and, therefore, is unlikely to create any significant omission bias. We have used the input and output data per farm basis due to our intention to estimate the TFP, TEC and TC changes of farm-households over the time periods, though sometime it is arguable that estimates based on input and output data per unit of land give better results. The average rice output of farm households has declined over time. This may have happened due to 
declining soil fertility and rice mono-culture practice by the farm-households. The average cultivated land and the input use levels (seed, fertilizer, labour and pesticides) also declined over time.

$<$ Table 2 near here $>$

\section{Empirical model and hypotheses tests}

A flexible translog stochastic production frontier is postulated as shown below:

$$
\begin{gathered}
\ln Y_{i t}=\beta_{0}+\sum_{n=1}^{N} \beta_{n} \ln X_{n i t}+\frac{1}{2} \sum_{n=1}^{N} \sum_{j=1}^{N} \beta_{n j} \ln X_{n i t} \ln X_{n i t}+\delta_{1} D_{2000}+\delta_{2} D_{2004}+V_{i t}-U_{i t} \\
\text { Where, } \mathrm{i}=1,2 \ldots \ldots 73 \text { and } \mathrm{t}=1,2,3
\end{gathered}
$$

where, $\ln \mathrm{Y}$ is the $\log$ of rice output, and the five independent variables $\left(\ln \mathrm{X}_{\mathrm{i}}\right)$ are the $\log$ of land, seed, fertilizer, labour and pesticides. The variables were mean differenced (i. e., $X_{i}^{*}=X_{i}-\bar{X}$ ) prior to estimation in order to allow for direct estimation of the output elasticities. In this model, to capture technical change we use dummy variable of year 2000 and 2004. This model also incorporates a simple exponential specification of the timevarying inefficiencies following Coelli and Battese (1996).

The maximum-likelihood estimates of the parameters of translog stochastic frontier production function defined by equation (6) are obtained by using R package `frontier` (Coelli and Henningsen, 2010). A series of formal hypothesis tests were conducted to determine the preferred functional form and the distribution of the random variables associated with the existence of technical inefficiency and the residual error term. The results of the hypotheses tests using likelihood ratios (LR) are presented in Table 3.

$<$ Table 3 near here $>$

A test of hypothesis on the choice of functional form confirms that the choice of translog production function is a better representation of the production technology. The null 
hypothesis that the $\mathrm{CD}$ production function is an adequate representation for the rice data $\left(H_{0}: \beta_{j k}=0\right)$ for all $j k$ is strongly rejected.

The parameter $\gamma$ is the ratio of the error variances that is $\gamma=\sigma_{u}{ }^{2} /\left(\sigma_{v}{ }^{2}+\sigma_{u}{ }^{2}\right)$. The value of $\gamma$ vary between zero and one, if the value of $\gamma=0$, it means that technical inefficiency is not present, and if $\gamma=1$ it means that there is no random noise. The test of significance of the inefficiencies in the model rejected the null hypothesis $\left(H_{0}: \mu=\gamma=0\right)$, indicating that it is a significant improvement over a simple OLS specification and inefficiencies do exit. The null hypothesis that there is no technical change over time $\left(H_{0}: \beta_{5}=\beta_{51}=\beta_{55}=0\right)$ is also strongly rejected indicating that technical change exists in rice production in Bangladesh. Finally, the hypothesis that technical inefficiency of the farm is time invariant $\left(H_{0}: \eta=0\right)$ is rejected, indicating that technical efficiency levels vary significantly over time.

\section{Results and discussions}

The parameter estimates from the translog stochastic frontier production function are presented in Table 4.

$<$ Table 4 near here $>$

From Table 4, it is evident that all basic inputs other than labour and fertilizer significantly influence rice production in Bangladesh. Out of all five inputs, seed and land appears to be the major determinants of rice production growth. The estimated coefficients of land, seed, and pesticides are significantly different from zero. Moreover, the dummy variable of year 2000 and 2004 incorporated to capture technical change are also significant.

Since mean-differenced variables are used in the estimation of the translog model, the output elasticities are simply the coefficients on the first order terms.

Seed remains as the single most important input with an output elasticity of 0.59 followed by land at 0.30 , labour at 0.06 , fertilizer at 0.05 and pesticides 0.04 respectively. The implication is that a $10 \%$ increase in seed use will increase output by $5.9 \%$. Similarly, a $10 \%$ 
increase in land use will increase output by $3 \%$ and so on. The elasticity associated with seed is the largest one which is not surprising at all. A similar conclusion was also drawn by Hossain et al., (2006). They showed that the expansion was relatively slow during 1970s but the expansion of modern varieties (MVs) of seed took place faster after market reforms and by $2001-02$, the coverage of MVs reached $65 \%$ of the rice-cropped area.

Though there is seasonality of labour which makes labour shortage for critical agricultural operations, in general Bangladesh is a labour surplus economy. Labour has a lower (0.06) output elasticity which, however, is not statistically significant. The sum of the first order coefficients of the input variables also provides a measure of the returns to scale. The sum is equal to 1.04 suggesting constant returns to scale at the sample mean point. The null hypothesis with regard to the constant return to scale was tested and accepted (see Table 3). The significant coefficient of dummy variable 2000 and 2004 indicates that there is positive technical change over the 17 year period (1987 to 2004) that has significantly contributed to output growth. However, the coefficient values of dummy variable for 2000 and 2004 also indicate that technical change declined from 2000 to 2004.

The value of $\gamma$ is 0.33 and is highly statistically significant, implying that $33 \%$ of the variation in the composite error term is due to the inefficiency component (see Table 4). This implies that about $33 \%$ of the differences between the observed output and maximum production frontier output were caused by differences in rice farmers' levels of technical efficiency, which is also supported by the LR test result in Table 3.

The significant negative coefficient on $\eta$ (the time-varying efficiency effect) indicates that technical efficiency declined over time. Rahman (2007) attributed to falling efficiency to: (a) depletion of nutrients from the soil due to higher nutrient uptake in the form of rice harvest which exacerbated with the use of lower than recommended level of fertilization to replenish the soil; and (b) the re-use of MV rice seeds from one generation to the next which compromise genetic purity. This is because these self-pollinated MVs require replacement in 
4-5 years to maintain their productivity, a practice which is not strictly followed by majority of farmers. The value of $\eta$ is -0.52 and is statistically significant (see Table 4). Coelli et al., (2003) also found a similar result indicating that the technical efficiency declined at the rate of $0.21 \%$ per annum during 1962-1991 periods.

A relevant question is therefore to analyse what factors are associated with technical efficiency declines? Prior to the discussion of these factors, we present the distribution of farm specific efficiency scores in Table 5 . It is evident from Table 5 that the mean efficiency level has declined over time. In 1987 it was $85 \%$, in 2000 it stands at $76 \%$ and in 2004 it reduced to $63 \%$. The declining mean efficiency level over time indicates that rice production could be increased substantially by eliminating inefficiency alone without additional use of resources. The estimates of 1987 and 2000 are slightly lower than those reported by Rahman (2003), Wadud and White (2000), and Sharif and Dar (1996). Salim and Hossain (2006) argued that only few farmers are producing close to the production frontier while many of the farmers are not; with only $6 \%$ to $9 \%$ of the sample farms producing between $86 \%$ to $100 \%$ efficiency levels whereas $40 \%$ of the farmers are producing below $55 \%$ efficiency level. Coelli et al., (2002) reported technical efficiency in Bangladesh to be $66 \%$ and $69 \%$ for Aman and Boro rice respectively.

$<$ Table 5 near here $>$

One of our main objectives was to estimate farm level TFP growth and its components: TEC and TC. The indices for changes in TFP, TEC and TC for the period of 1987 to 2000 and 2004 are presented in Table 6. The evolution of TC was positive from 1987 to 2004, whereas it was negative for TEC. A positive change in TC implies an improvement of technology over time. However, TFP change was also positive from 1987 to 2000 and 2004 but lower in 2004. The positive but declining TFP change is due to the results of the offsetting effects of efficiency decline (negative) against technical progress decline (positive). 
Recall that our estimate of the dummy 2000 and 2004 are 0.58 and 0.57 respectively (see Table 4) which means that the frontier shifted upward by $58 \%$ from 1987 to 2000 and by $57 \%$ from 1987 to 2004. It declined slightly from 2000 to 2004. The rate of technical progress in 2000 and 2004 conform with the value of the coefficients on the dummy variables in the production function. TFP change is also positive from 1987 to 2000 and 1987 to 2004 but it also declined during 2000 to 2004 . To explain this phenomena, the trend of rice production is presented in Figure 1. It is evident that, production was less stable during 1987-2000. We observe fluctuation of the production level which could have influenced the result of TFP changes. However, in 2000 the country observed a bumper production but in 2004 production declined from its 2000 level.

$<$ Figure 1 near here $>$

However, it is evident from our results, that over the 17 years (1987-2004) period, the TFP growth remains positive largely due to an upward shift in the technology. Technical efficiency is negative over the observed years at farm level in Bangladesh.

Next, the question arises what factors are associated with TEC, TC and TFP changes. The variables most often used in the literature (Kamruzzaman et al., 2007; Coelli et al., 2002; Wilson et al., 2001; Wadud and White, 2000; Bravo-Ureta and Evenson, 1994) to explain varying efficiencies are- age of the farmers, educational background, households size, farm size, off farm income, owned land etc. We have used all of these farm level information from our cohort data source (the samples belong to years, 1987, 2000 and 2004). However, keeping in mind the objective to find out the magnitude of influences of market reform policy on TFP and its components (TEC and TC), we added a national level variable, the effective protection coefficient (EPC) as an explanatory variable to capture its influence on these indices. It is worthy to mention that the EPC is defined as the ratio of value added at domestic prices to value added at world reference prices, where value added refers to the difference between output price and the value of all traded inputs used to produce one unit of 
output. An EPC value of greater than 1 suggests that government policies provide positive incentives to producers, while values less than 1 indicate that producers are less protected because of the liberalization. EPC take into account the customs duty and other protection measures on both the input and output markets and thus, explain the situation of market protection. In our study we did not calculate EPC due to the fact that calculating EPC needs economic analysis of input and output prices considering the shadow prices that are beyond our scope. Hence we have used EPC value for Bangladesh from a recent study (Rashid, 2009) sponsored by FAO. Rashid (2009) estimated EPC in rice production to be 2.26 for 1986/87 which was higher than the estimates of 0.80 for $1999 / 2000$ and 0.65 in 2003/04. The decrease of EPC value is the logical outcome of the liberalization policies in both the input and output markets in Bangladesh. We have used Rashid's (2009) EPC measures in our study.

Thus, the indices of TEC, TC and TFP are separately regressed with the following explanatory variables: age, education, household size, farm size, tenancy, off farm work and EPC change. Their OLS estimates are reported in Table 7.

Age variable has expected negative signs and is significant in all three models. The negative coefficient of age in explaining TEC implies that older farmers are technically less efficient than younger farmers. This could be explained in terms of the adoption of new technology. Older farmers are likely to be more conservative and less receptive to new technologies and practices than younger farmers. Balcombe et al., (2008) and Wadud and White (2000) also reported similar results in their studies on Bangladesh.

Education (schooling years) is used as a proxy for managerial input. Higher levels of education may lead to better assessment of farming issues and better farming decisions. However, overall the educational level of the people engaged in agricultural farming in Bangladesh is very low because agriculture is less rewarding for higher educated people therefore it is unlikely that highly educated peoples remain in agricultural farming as 
profession. However, education does not have the expected sign but is significant in all three models. The negative influence of education on technical efficiency was also reported by Rahman and Shankar (2009), Coelli et al., (2003), Wadud and White (2000) and Hossain (1989). Rahman and Shankar (2009) noted that education gives better opportunities to move away from agriculture to non-agriculture where the farmers are better rewarded. Coelli et al., (2003)noted that education in Bangladesh is not correlated to efficiency because the average level of education is low ( $<4$ years of schooling).

Both farm size and household size variables are significant in all three models and has expected sign. The farm size positively influences TEC meaning that larger farms are more efficient than smaller farms. It is very likely that large farms can promptly fully utilize existing resources as well as having a greater ability to access modern input. Kamruzzaman et al., (2007) also reported similar results for Bangladesh. Rahman and Rahman (2008) also reported household size has positive impact on technical efficiency in their studies on Bangladesh. The implication of positive sign of household size is that larger households can substitute hired farm workers by family workers and, therefore, affect positively rice production efficiency. Rahman and Rahman (2008) also reported household size has positive impact on technical efficiency in their studies on Bangladesh.

Tenancy (proportion of rented-in land cultivated by the farm household) has negative impact in TEC, TC and TFP change model and also is significant. It means that farms with a large proportion of rented land are less efficient than owners. This sign is expected, as Rahman and Rahman (2008), Salim and Hossain (2006) and Coelli et al., (2002), also reported that tenancy has a negative impact on technical efficiency.

off-farm work has a significant negative impact on TE, TC and TFP change in all three models. If farmer has chance to engage off farm work then it is natural that they pay less attention to rice farming relative to other farmers. Thus, opportunities for off farm work 
reduces technical efficiency, as expected. Rahman and Rahman (2008) and Balcombe et al., (2008) also reported similar results in their studies on Bangladesh.

$<$ Table 7 near here $>$

Market reform policy has a mixed impact in a developing country like Bangladesh. The neoclassical economists argue that market liberalization accelerates economic growth while protection leads to misuse of resources, hence adversely affects economic development. On the contrary, the critics argue that openness has its costs and sometimes could be detrimental to economic development (Chang et al., 2005; Rodriguez and Rodrik, 1999). In our study the contribution of the EPC change has the expected positive and significant impact on both TC and TFP with highest value of the coefficient which proves its dominant influence on rice production in Bangladesh. However, impact of EPC on efficiency change is negative. The plausible reasons for positive TC and TFP are as follows. HYV seeds, irrigation and fertilizers were the three critical elements of the technology package in rice production in Bangladesh. The farmers gained access to this technology package gradually over time. Use of HYV seed in rice production has increased over time, now two- thirds of the rice area is planted with modern varieties. Irrigation has been provided to half of the land area under rice. Fertilizer application has reached an average level of $114 \mathrm{~kg}$ per acre against only $19.4 \mathrm{~kg}$ in the late $1970 \mathrm{~s}$ and liberalization of the import of agricultural equipment (shallow tube well engines and power tiller), particularly the removal of restrictions on import conditioned by public specification standards, made these equipments cheaper and have motivated farmers to use and adopt them (Ahmed, 2004). Use of high yielding varieties of rice, widespread expansion of modern irrigation technology, use of chemical fertilizers and a sharp rise in pesticide applications were the principle causes of positive technical progress. Thus it is not unlikely that the market reform policies have removed various distortions in rice input and output markets and, therefore, enhanced 
farmers' accessibility to modern technologies and market information, which might have contributed to TFP increases.

The detrimental impact of EPC on TEC in rice farming is not unexpected. Although it is expected that market reform policy removed all distortions from the input and output markets which could augment farmers' accessibility to modern technologies and market information, thereby, making them more efficient, our results show that the farmers were more efficient in the pre-market reform period. As indicated earlier, one cause for falling efficiency could be re-use of MVs rice seeds. If farmers re-use MVs and mix of MV seeds with their own inferior strains, then obviously productivity of seed will decline and increase inefficiency. Another factor could be -the use of lower doses of fertilizers than recommended leading to a decline in soil fertility. Ahmed (2001) showed that fertilizer use for rice production is about $40-45 \%$ below the recommended doses. Moreover, the use of phosphate and potassium fertilizers are very important for preventing sterilization in grains but it is about $60-70 \%$ below the recommended doses (Ahmed, 2001). Poor contact of the farmers with agriculture extension personnel could be another reason. Hossain et al., (2004) found that only $12 \%$ of the farmers have been getting information on MVs from extension officials. The adoption of MVs occurred, however, through informal farmer to farmer exchange and learning by doing rather than through extension services. Moreover, input market is not free from mismanagement in Bangladesh, for example, fraudulent practices in selling and distribution of fertilizers by traders are often reported in newspapers. Bhattacharya and Titumir (2001) found that the incidence of sale of low quality inputs at high price have become very frequent, emerging as a great problem in the agricultural input markets. The farmers are being cheated from buying low quality inputs such as cement mixed fertilizers, seeds and pesticides which lead to a decline in soil fertility whilst also paying exorbitant prices (Azmat and Coghill, 2005). Furthermore, the spread of modern technology has largely bypassed some districts located in low elevation and coastal area of Bangladesh 
(Soussan and Datta, 1998). All of these can be plausible reasons explaining negative technical efficiency variability and thus higher differences in efficiency. A study of Salim and Hossain (2006) showed that the effective rate of assistance has a negative impact on efficiency change.

\section{Conclusions and policy implications}

Higher TFP growth in agriculture is desirable as it is a fundamental precondition to sustain the sector and the role of market policy reforms was to remove all types of inefficiency thereby raising productivity in Bangladesh. In this study we have attempted to estimate growth in TFP, TC and TEC of rice production at the farm-level in Bangladesh and trace whether market reforms had any influence on these indices. Results revealed that over the studied period (1987-2004), TFP has increased significantly mainly due to an upward shift of the technology frontier but it declined from its peak in later periods. TFP declined during 1987 to 2004 as compared to $1987-2000$ but remains positive. This happened due to the fact that the bulk of liberalization policies took place after the mid-1990s. Although TFP and TC have increased, TEC has declined,

We found that EPC change has a positive effect on TFP and TC but negative effect on TEC. The results indicate that a liberalized market stimulated possibilities for technological progress. Because of the liberalization in the agricultural input and output markets, the private sectors participated in varietal developments and its dissemination, distribution of irrigation equipments and chemical fertilizers. All of these have stimulated technological progress in Bangladesh agriculture, particularly rice production. However, the liberalized market comes perhaps together with a less protected environment for all market players. The increase in technical inefficiency, which is a measurement of inequality, indicates that not all farmers can benefit equally from the new opportunities available from liberalized markets. 
Other positively contributing factors to changes in TEC, TC and TFP levels are household size and farm size whereas education, age, land ownership (tenancy) and off-farm work opportunities influenced these indices negatively.

The following policy implications can be drawn from this study. First, the market liberalization policies should be continued as it has significantly improved TFP and TC. However, to tackle the negative impact of market liberalization on TEC, farmers need to be supported through improved agricultural extension services to enable them to catch up with technological progress and market information. Rahman and Salim (2013) noted significant impact of extension expenditure in improving mix efficiency change (which is included in our broader definition of technical efficiency change), i. e., enabling farmers to derive scope economies from their production process by changing input and output mixes to optimal levels. Rahman and Rahman (2008) also noted significant positive influence of extension contact on technical efficiency in rice production in Bangladesh. Second, undertaking land reform measures aimed at increasing farm size by land consolidation. Rahman and Salim (2013) also noted that the average farm size is the most dominant factor in influencing TFP growth and various efficiency measures in Bangladesh. The average farm size in Bangladesh has been falling steadily from 1.4 ha in 1960 to 0.60 ha in 2008 (Rahman and Salim, 2013). One major factor reducing farm size is land fragmentation which in turn significantly reduces technical efficiency and productivity (Rahman and Rahman, 2008). Rahman and Rahman (2008) recommended addressing the structural causes of land fragmentation through modification of the law of inheritance and regulations to prevent land fragmentation, which we also support. Effective implementation of these policy measures will improve productivity growth in rice which is a goal worth pursuing. 


\section{References}

Ahmed, A., 2001. Retrospects and Prospects of the Rice Economy of Bangladesh. University Press Limited, Dhaka, Bangladesh.

Ahmed, R., 2004. Rice economy of Bangladesh: progress and prospect. Economic and Political Weekly, 39 (36), 4043-4052.

Azmat, F., and Coghill, K., 2005. Good governance and market-based reforms: a study of Bangladesh. International Review of Administrative Sciences, 71, 625-638.

Balcombe, K., Fraser, I., Latruffe, L., Rahman, M., and Smith, L., 2008. An application of the DEA double bootstrap to examine sources of efficiency in Bangladesh rice farming. Applied Economics, 40, 1919-1925.

BBS, 2009. Statistical Yearbook in Bangladesh. Bangladesh Bureau of Statistics, Statistics Division, Ministry of Planning, Government of the People's Republic of Bangladesh, Dhaka, Bangladesh.

Bhattacharya, D., and Titumir, R., 2001. Bangladesh's Experience with Structural Adjustment: Learning from a Participatory Exercise. Draft Paper presented on the Second National forum of SAPRI, Bangladesh.

Bravo-Ureta, B. E., and Evenson, R. E., 1994. Efficiency in agricultural production: the case of peasant farmers in eastern Paraguay. Agricultural Economics, 10, 27-37.

Chang, R., Kaltani, L., and Loayza, N., 2005. Openness Can be Good for Growth: The Role of Policy Complementarities. NBER Working Paper 11787, Cambridge: National Bureau of Economic Research.

Coelli, T. J., and Battese, G. E., 1996. Identification of factors which influence the technical inefficiency of Indian farmers. Australian Journal of Agricultural Economics, 40, 103128.

Coelli, T. J., Rahman, S., and Thirtle, C., 2002. Technical, allocative, cost and scale efficiencies in Bangladesh rice cultivation: a non-parametric approach. Journal of 
Agricultural Economics, 33(3), 605-624.

Coelli, T. J., Rahman, S., and Thirtle, C., 2003. A stochastic frontier approach to total factor productivity measurement in Bangladesh crop agriculture 1961-92. Journal of International Development, 15, 321-333.

Coelli, T. J., Rao, D., O’Donnell, C., and Battese, G., 2005. An Introduction to Efficiency and Productivity Analysis. Kluwer: Boston.

Coelli, T., and Henningsen, A., 2010. Package 'frontier', Stochastic Frontier Analysis Version 0.996-10, http://www.uq.edu.au/economics/cepa/ and http://frontier.r-project.org/

David, C. C., and Otsuka, K., 1994. Modern Rice Technology and Income Distribution in Asia. Lynne Reiner Publishers, Boulder, Colorado.

FAO, 2008. FAOStat Statistical Database of Food and Agriculture Organization of the United Nations, Rome.

Fan, S., Hazell, P., and Thorat, S., 2000. Government spending, growth and poverty in rural India. American Journal of Agricultural Economics, 82: 1038-1051

Fare, R., Grosskopf, S., and Lovell, C. K., 1985. The Measurement of Efficiency of Production. Luwer- Nijhoff: Boston.

Gong, B., and Sickles, R., 1992. Finite sample evidence on the performance of stochastic frontiers and data envelopment analysis using panel data. Journal of Econometrics, 51 , 259-284.

Hossain, M., 1989. Green Revolution in Bangladesh: Impact on Growth and Distribution of Income. University Press Limited, Dhaka, Bangladesh.

Hossain, M., David, L., Manik L. B., and Chowdhury. A., 2006. Rice Research, Technological Progress and Poverty. pp 56-102 in Michelle Adato and Ruth Meinzen-Dick (eds) Agricultural Research, Livelihoods and Poverty: Studies of Economic and Social Impact in Six Countries. Baltimore: the Johns Hopkins University Press. 
Hossain, M., Lewis, D., Bose, L., M. and Chowdhury, A., 2004. Rice Research, Technological Progress and Impact on the Poor. The Bangladesh Case (summary report), EPTD Discussion paper No. 110. IFPRI, Washington, D.C.

Hossain, M., Naher, F., and Shahabuddin, Q., 2005. Food security and nutrition in Bangladesh: progress and determinants. Electronic Journal of Agricultural and Development Economics, 2(2), 103-132.

Hossain, M., Quasem, M. A., Jabbar, M. A., and Akash, M. M., 1994. Production environments, modern variety adoption, and income distribution in rural Bangladesh. In: David, C. C., Otsuka, K. (Eds.), Modern Rice Technology and Income Distribution in Asia. Lynne Reiner Publishers, Boulder, Colorado.

Kamruzzaman, M., Manos, M., and Begum, A. A., 2007. Evaluation of economic efficiency of wheat farms in a region of Bangladesh under the input orientation model. Journal of the Asia Pacific Economy, 11(1), 123-142.

Mukherjee, A. N., Kuroda, Y., 2003. Productivity growth in Indian agriculture: is there evidence of convergence across states? Agricultural Economics, 29: 43-53.

O`Donnel, C. J., 2010. Measuring and decomposing agricultural productivity and profitability change. Austratian Journal of Agricultural and Resource Economics, 54: 527560 .

Ondrich, J., and Ruggiero, J., 2001. Efficiency measurement in the stochastic frontier model. European Journal of Operational Research, 129, 434-442.

Rahman, H. Z., and Hossain, M., 1995. Rethinking Rural Poverty: Bangladesh as a Case Study. New Delhi, London: Sage Publications.

Rahman, S., 2003. Profit efficiency among Bangladeshi rice farmers. Food Policy, 28, 487503.

Rahman, S., 2007. Regional productivity and convergence in Bangladesh agriculture. The Journal of Developing Areas, 41(1), 221-236. 
Rahman, S. and Rahman, M., 2008. Impact of land fragmentation and resource ownership on productivity and efficiency: The case of rice producers in Bangladesh. Land Use Policy, 26, 95-103.

Rahman, S. and Shankar, B., 2009. Profits, supply and HYV adoption in Bangladesh. Journal of the Asia Pacific Economy, 14(1), 73-89.

Rahman, S. and Salim, R., (2013). Six decades of total factor productivity change and sources of growth in Bangladesh agriculture (1948-2008). Journal of Agricultural Economics, 63(2): 273-294.

Rashid, M. A., 2009. Trade policies and comparative advantage in Bangladesh agriculture. Unpublished PhD Thesis, Department of Agricultural Economics, Bangladesh Agricultural University, Mymensingh.

Rodriguez, F. and Rodrik, D., 1999. Trade Policy and Economic Growth; A Skeptic's Guide to the Cross-National Evidence. NBER Working Paper 7081, Cambridge: National Bureau of Economic Research.

Ruggiero, J., 1999. Efficiency estimation and error decomposition in the stochastic frontier model: a Monte Carlo analysis. European Journal of Operational Research, 115, 555563.

Salim, R. and Hossain, A., 2006. Market deregulation, trade liberalization and productive efficiency in Bangladesh agriculture: an empirical analysis. Applied Economics, 38(21), 2567-2580.

Selim, S., 2007. Labour Productivity and Rice Production in Bangladesh: A Stochastic Frontier Approach. Cardiff Economics Working Paper E 2007/10.

Sharif, N. R. and Dar, A. A., 1996. An empirical study of the pattern and sources of technical inefficiency in traditional and HYV rice cultivation in Bangladesh. Journal of Development Studies, 32 (2), 612-629. 
Sickles, R., 2005. Panel estimators and the identification of firm-specific efficiency levels in parametric, semi parametric and nonparametric settings. Journal of Econometrics, 126, 305-334.

Soussam, J. and Datta, A., 1998. Community Partnership for Sustainable Water Management: Experience of BWDB System Rehabilitation Project. Vol. 1, University Press, Dhaka.

Wadud, M. and White, B., 2000. Farm household efficiency in Bangladesh: a comparison of stochastic frontier and DEA methods. Applied Economics, 32, 1665-1673.

Wilson, P., Hadley, D. and Asby, C., 2001. The influence of management characteristics on the technical efficiency of wheat farmers in eastern England. Agricultural Economics 24, 329-338.

Winston, H. Yu., Alam, M., Ahmadul H.,, Abu, S. K., Alex C. R., Cynthia, R., David, C. M., and James, T., 2010. Climate Change Risks and Food Security in Bangladesh. World Bank. 
Table 1: Summarization of market reform policies in Bangladesh.

\begin{tabular}{|c|c|c|c|}
\hline Periods & Policies & Purposes & Observed outcomes \\
\hline $\begin{array}{l}\text { Pre-reform } \\
(1977-1989)\end{array}$ & $\begin{array}{l}\text { - Huge input subsidy } \\
\text { - Quantity rationing } \\
\text { - } \text { Differentiated tariffs rates } \\
\text { - Input distribution } \\
\text { through government } \\
\text { - Channel } \\
\text { - } \text { Price control ceiling } \\
\text { - Output price support }\end{array}$ & $\begin{array}{l}\text { - Self sufficiency in } \\
\text { food production } \\
\text { - Protecting } \\
\text { domestic farmers } \\
\text { from competition } \\
\text { - High production } \\
\text { growth } \\
\text { - Reducing } \\
\text { production cost of } \\
\text { farmers }\end{array}$ & $\begin{array}{l}\text { - Low output } \\
\text { growth } \\
\text { - Slow rate of } \\
\text { technology } \\
\text { adoption }\end{array}$ \\
\hline $\begin{array}{l}\text { Post-reform } \\
(1990-2004)\end{array}$ & $\begin{array}{l}\text { - Deregulation of input } \\
\text { subsidy } \\
\text { - } \text { Reducing government } \\
\text { control in agricultural } \\
\text { input \& output markets } \\
\text { - Lowering tariffs and non- } \\
\text { tariff barriers } \\
\text { - Food grain importation } \\
\text { by private sector } \\
\text { - Gradual elimination of } \\
\text { public food grain } \\
\text { distribution } \\
\text { - Price stabilization } \\
\text { through open tender } \\
\text { procurement } \\
\text { Permitting private sector } \\
\text { in the procurement of } \\
\text { fertilizers and irrigation } \\
\text { equipment }\end{array}$ & 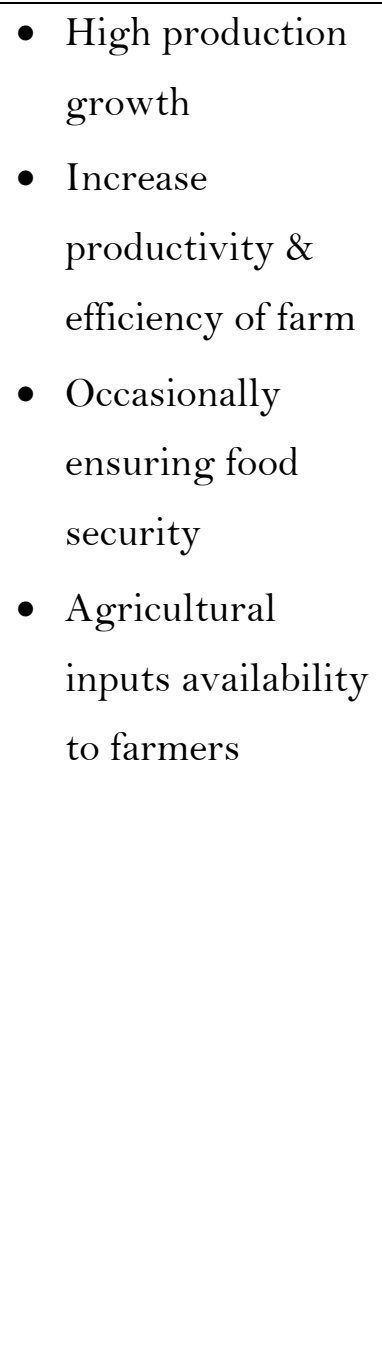 & $\begin{array}{l}\text { - } \text { Boro Rice } \\
\text { production } \\
\text { increased } \\
\text { - Less than } \\
\text { projected growth } \\
\text { in production of } \\
\text { hybrids crops }\end{array}$ \\
\hline
\end{tabular}

Source: Selim (2007); Salim and Hossain (2006) 


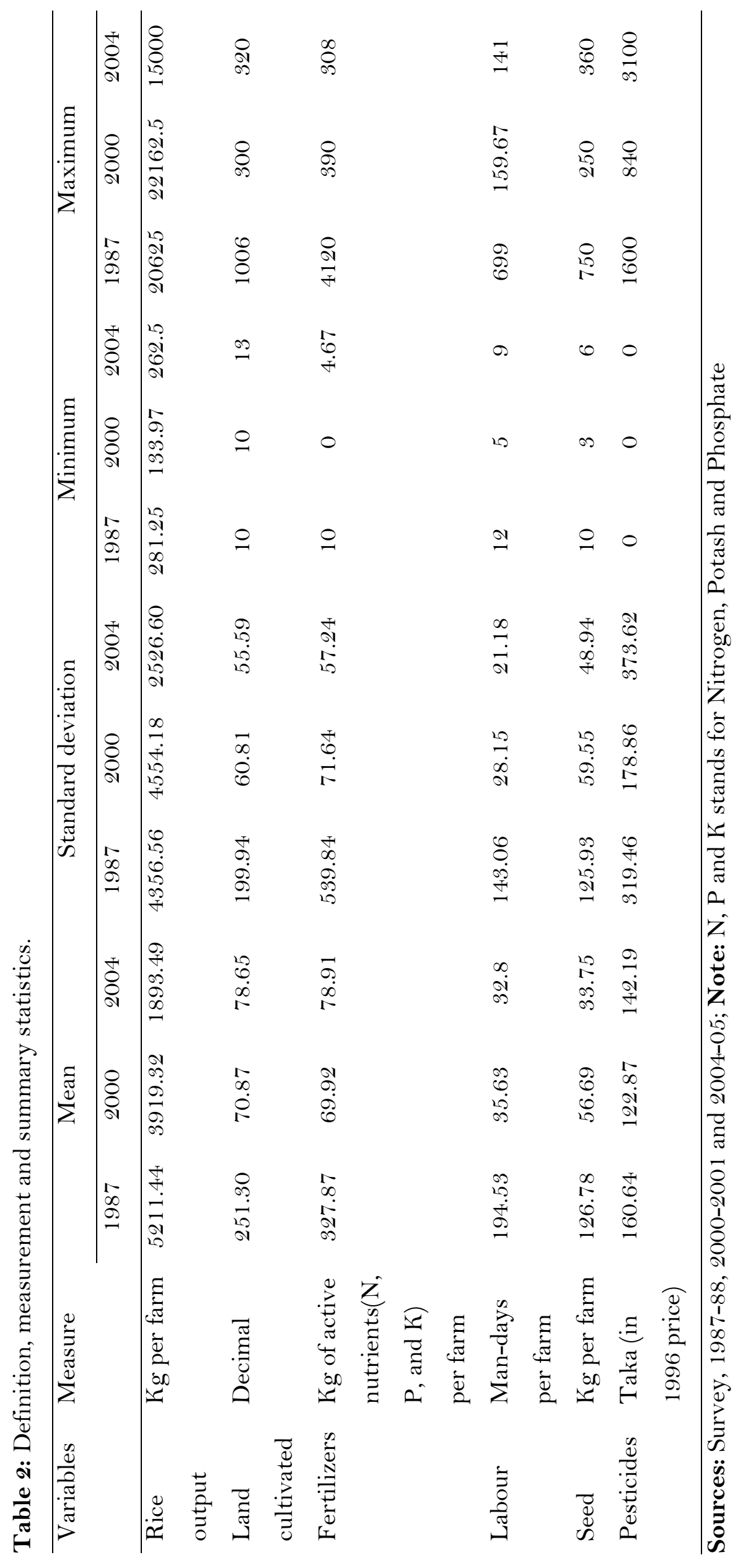


Table 3: Hypotheses tests.

\begin{tabular}{|c|c|}
\hline Null Hypotheses & Test results \\
\hline \multicolumn{2}{|l|}{$\begin{array}{l}\text { Choice of functional form - Cobb-Douglas (CD) vs translog } \\
\left(H_{0}: \beta_{j k}=0\right) \text { for all } j k\end{array}$} \\
\hline LR test statistic $\left(\chi^{2}\right)$ & 83.61 \\
\hline Degrees of freedom & 21 \\
\hline$p$-value (Prob. $\left.>\chi^{2}\right)$ & 0.00 \\
\hline Decision & rejected \\
\hline \multicolumn{2}{|l|}{$\begin{array}{l}\text { Production structure exhibits constant returns to scale } \\
\left(H_{0}: \sum \beta_{j}=1\right) \text { for all } j\end{array}$} \\
\hline LR test statistic $\left(\chi^{2}\right)$ & 1.69 \\
\hline Degrees of freedom & 1 \\
\hline$p$-value $\left(\right.$ Prob $\left.>\chi^{2}\right)$ & 0.1939 \\
\hline Decision & accepted \\
\hline \multicolumn{2}{|l|}{ No inefficiencies are present in the model $\left(H_{0}: \mu=\gamma=0\right)$} \\
\hline LR test statistic $\left(\chi^{2}\right)$ & 16.53 \\
\hline Degrees of freedom & 5 \\
\hline$p$-value (Prob. $\left.>\chi^{2}\right)$ & 0.000 \\
\hline Decision & rejected \\
\hline \multicolumn{2}{|l|}{ No technical change over time $\left(H_{0}: \beta_{5}=\beta_{51}=\beta_{55}=0\right)$} \\
\hline LR test statistic $\left(\chi^{2}\right)$ & 32.63 \\
\hline Degrees of freedom & 6 \\
\hline$p$-value $\left(\right.$ Prob $\left.>\chi^{2}\right)$ & 0.000 \\
\hline Decision & rejected \\
\hline \multicolumn{2}{|l|}{ Technical inefficiencies are time invariant $\left(H_{0}: \eta=0\right)$} \\
\hline LR test statistic $\left(\chi^{2}\right)$ & 4.24 \\
\hline Degrees of freedom & 1 \\
\hline$p$-value $\left(\right.$ Prob $\left.>\chi^{2}\right)$ & 0.000 \\
\hline Decision & rejected \\
\hline
\end{tabular}


Table 4: Maximum likelihood estimates of the stochastic production frontier model.

\begin{tabular}{|c|c|c|c|}
\hline \multirow[t]{2}{*}{ Regressors } & \multicolumn{3}{|c|}{ Translog model } \\
\hline & Parameter & Coefficient & t-ratio \\
\hline \multicolumn{4}{|l|}{ Production function } \\
\hline constant & $\mathrm{a}$ & $-0.408^{* * * *}$ & -3.13 \\
\hline land(decimal) & $\mathrm{x}_{1}$ & $0.306^{* * * *}$ & 3.64 \\
\hline labour(man-day) & $\mathrm{x}_{2}$ & 0.056 & 0.65 \\
\hline fertilizer(kg) & $\mathrm{x}_{3}$ & 0.052 & 1.16 \\
\hline $\operatorname{seed}(\mathrm{kg})$ & $\mathrm{x}_{4}$ & $0.597^{* * * *}$ & 14.20 \\
\hline pesticides & $\mathrm{x}_{5}$ & $0.041^{* * * *}$ & 3.28 \\
\hline $\operatorname{land}^{2}$ & $\mathrm{x}_{11}$ & 0.019 & 0.06 \\
\hline labour ${ }^{2}$ & $\mathrm{x}_{22}$ & 0.029 & 0.12 \\
\hline fertilizer $^{2}$ & $\mathrm{X}_{33}$ & -0.020 & -0.49 \\
\hline seed $^{2}$ & $\mathrm{X}_{44}$ & $0.131^{*}$ & 1.96 \\
\hline pesticides $^{2}$ & $\mathrm{x}_{55}$ & $0.016^{* * * *}$ & 3.01 \\
\hline land*labour & $\mathrm{x}_{1} \mathrm{x}_{2}$ & $0.417^{* *}$ & 1.88 \\
\hline land*fertilizer & $\mathrm{x}_{1} \mathrm{x}_{3}$ & -0.109 & -1.11 \\
\hline land*seed & $\mathrm{x}_{1} \mathrm{x}_{4}$ & $-0.208^{* *}$ & -1.94 \\
\hline land*pesticide & $\mathrm{x}_{1} \mathrm{x}_{5}$ & $-0.024^{*}$ & -1.72 \\
\hline labour*fertilizer & $\mathrm{x}_{2} \mathrm{x}_{3}$ & -0.029 & -0.37 \\
\hline labour*seed & $\mathrm{x}_{2} \mathrm{x}_{4}$ & $-0.265^{* * *}$ & -2.90 \\
\hline labour*pesticides & $\mathrm{x}_{2} \mathrm{X}_{5}$ & $0.035^{* * *}$ & 3.08 \\
\hline fertilizer*seed & $\mathrm{X}_{3} \mathrm{X}_{4}$ & $0.106^{* *}$ & 2.00 \\
\hline fertilizer*pesticide & $\mathrm{X}_{3} \mathrm{X}_{5}$ & -0.007 & -1.25 \\
\hline seed*pesticide & $\mathrm{x}_{4} \mathrm{X}_{5}$ & $-0.019^{* * *}$ & -3.34 \\
\hline dummy 2000 & $\mathrm{dx}_{1}$ & $0.580^{* * * *}$ & 4.31 \\
\hline dummy 2004 & $\mathrm{dx}_{2}$ & $0.575^{* * *}$ & 2.17 \\
\hline
\end{tabular}

\section{Diagonosis statistics}

\begin{tabular}{|c|c|c|c|}
\hline$\sigma 2$ & & $0.169^{* * *}$ & 6.31 \\
\hline$\gamma$ & & $0.330^{* * * *}$ & 2.51 \\
\hline$\mu$ & & 0.473 & 1.42 \\
\hline$\eta$ & & $-0.522^{* *}$ & -2.26 \\
\hline Log likelihood & & -90.41 & \\
\hline Number of observation & & 219 & \\
\hline Mean technical efficiency (\%) & 74.4 & & \\
\hline
\end{tabular}

Note: ***, ** and * indicates the level of significance at $1 \%, 5 \%$ and $10 \%$ respectively 
Table 5: Distribution of technical efficiency.

\begin{tabular}{lccc}
\hline Variable & 1987 & 2000 & 2004 \\
\hline Efficiency score & 0 & 16 & 58 \\
Up to $70 \%$ & 10 & 42 & 13 \\
$71-80 \%$ & 58 & 15 & 2 \\
$81-90 \%$ & 5 & 0 & 0 \\
$91-100 \%$ & 0.85 & 0.76 & 0.63 \\
Mean efficiency level & 0.04 & 0.06 & 0.09 \\
Standard deviation & 0.94 & 0.90 & 0.84 \\
Maximum & 0.75 & 0.62 & 0.45 \\
Minimum & & & \\
\hline
\end{tabular}


Table 6: Cumulative percentage change measure of TEC, TC and TFP.

\begin{tabular}{cccc}
\hline Year & $\begin{array}{c}\text { Technical Efficiency } \\
\text { Change } \\
(\text { TEC })\end{array}$ & $\begin{array}{c}\text { Technical Change } \\
(\mathrm{TC})\end{array}$ & $\begin{array}{c}\text { Total Factor Productivity } \\
\text { Change (TFP) }\end{array}$ \\
\hline 1987 & 0 & 0 & 0 \\
2000 & -11.39 & 58.03 & 46.64 \\
2004 & -30.19 & 57.45 & 27.26 \\
\hline
\end{tabular}

Source: Author's estimation 
Table 7: Estimates of factors affecting changes in TEC, TC and TFP.

\begin{tabular}{|c|c|c|c|c|c|c|}
\hline \multirow[t]{3}{*}{ Regressors } & \multicolumn{6}{|c|}{ Dependent variable } \\
\hline & \multicolumn{2}{|c|}{ Model 1} & \multicolumn{2}{|c|}{ Model2 } & \multicolumn{2}{|c|}{ Model3 } \\
\hline & $\begin{array}{c}\text { Technical } \\
\text { efficiency } \\
\text { index }\end{array}$ & $\begin{array}{c}\text { Expected } \\
\text { sign }\end{array}$ & $\begin{array}{c}\text { Technical } \\
\text { change } \\
\text { index }\end{array}$ & $\begin{array}{c}\text { Expected } \\
\text { sign }\end{array}$ & $\begin{array}{l}\text { Total factor } \\
\text { productivity } \\
\text { index }\end{array}$ & $\begin{array}{c}\text { Expected } \\
\text { sign }\end{array}$ \\
\hline Constant & $\begin{array}{l}-0.0324 \\
(-0.02)\end{array}$ & & $\begin{array}{l}1.5221 \\
(0.71)\end{array}$ & & $\begin{array}{l}1.4896 \\
(0.36)\end{array}$ & \\
\hline Age & $\begin{array}{c}-0.1463^{* * *} \\
(-3.60)\end{array}$ & $\sqrt{ }$ & $\begin{array}{c}-0.1886^{* * *} \\
(-4.57)\end{array}$ & $\sqrt{ }$ & $\begin{array}{c}-0.3349^{* * *} \\
(-4.24)\end{array}$ & $\sqrt{ }$ \\
\hline Education & $\begin{array}{c}-0.2829^{* * * *} \\
(-3.11)\end{array}$ & $\mathrm{x}$ & $\begin{array}{c}-0.4122^{* * * *} \\
(-4.47)\end{array}$ & $\mathrm{x}$ & $\begin{array}{c}-0.6951^{* * *} \\
(-3.94)\end{array}$ & $\mathrm{x}$ \\
\hline $\begin{array}{l}\text { Household } \\
\text { size }\end{array}$ & $\begin{array}{c}0.3131^{* *} \\
(1.96)\end{array}$ & $\sqrt{ }$ & $\begin{array}{c}0.6172^{* * *} \\
(3.8)\end{array}$ & $\sqrt{ }$ & $\begin{array}{c}0.9303^{* * *} \\
(2.99)\end{array}$ & $\sqrt{ }$ \\
\hline Farm size & $\begin{array}{c}0.0073^{* * * *} \\
(3.15)\end{array}$ & $\sqrt{ }$ & $\begin{array}{c}0.0043^{*} \\
(1.81)\end{array}$ & $\sqrt{ }$ & $\begin{array}{c}0.0116^{* * *} \\
(2.56)\end{array}$ & $\sqrt{ }$ \\
\hline $\mathrm{EPC}$ & $\begin{array}{c}-5.3826^{* * * *} \\
(-5.83)\end{array}$ & $\mathrm{x}$ & $\begin{array}{l}49.21^{* * * *} \\
(52.49)\end{array}$ & $\sqrt{ }$ & $\begin{array}{l}43.82^{* * * *} \\
(24.42)\end{array}$ & $\sqrt{ }$ \\
\hline $\begin{array}{l}\text { Land } \\
\text { ownership } \\
\text { (tenurial } \\
\text { status) }\end{array}$ & $\begin{array}{c}-0.1630^{* *} \\
(-2.28)\end{array}$ & $\sqrt{ }$ & $\begin{array}{c}-0.1835^{* * *} \\
(-2.53)\end{array}$ & $\sqrt{ }$ & $\begin{array}{c}-0.3466^{* * *} \\
(-2.49)\end{array}$ & $\sqrt{ }$ \\
\hline Off farm work & $\begin{array}{c}-3.2669^{* * * *} \\
(-2.98)\end{array}$ & $\sqrt{ }$ & $\begin{array}{c}-5.2118^{* * * *} \\
(-4.69)\end{array}$ & $\sqrt{ }$ & $\begin{array}{c}-8.4788^{* * *} \\
(-2.49)\end{array}$ & $\sqrt{ }$ \\
\hline Adjusted $\mathrm{R}^{2}$ & 0.31 & & 0.93 & & 0.75 & \\
\hline $\begin{array}{l}\mathrm{F}(7,211) \\
\text { statistics }\end{array}$ & $14.79^{* * *}$ & & $417.35^{* * * *}$ & & $96.08^{* * *}$ & \\
\hline
\end{tabular}

Notes: $* * * * * *$ and $*$ indicates the level of significance at $1 \%, 5 \%$ and $10 \%$ respectively; the values in the parentheses indicates t-ratio 
Figure 1: Rice production ('OOO MT) over the year 1987-2004.

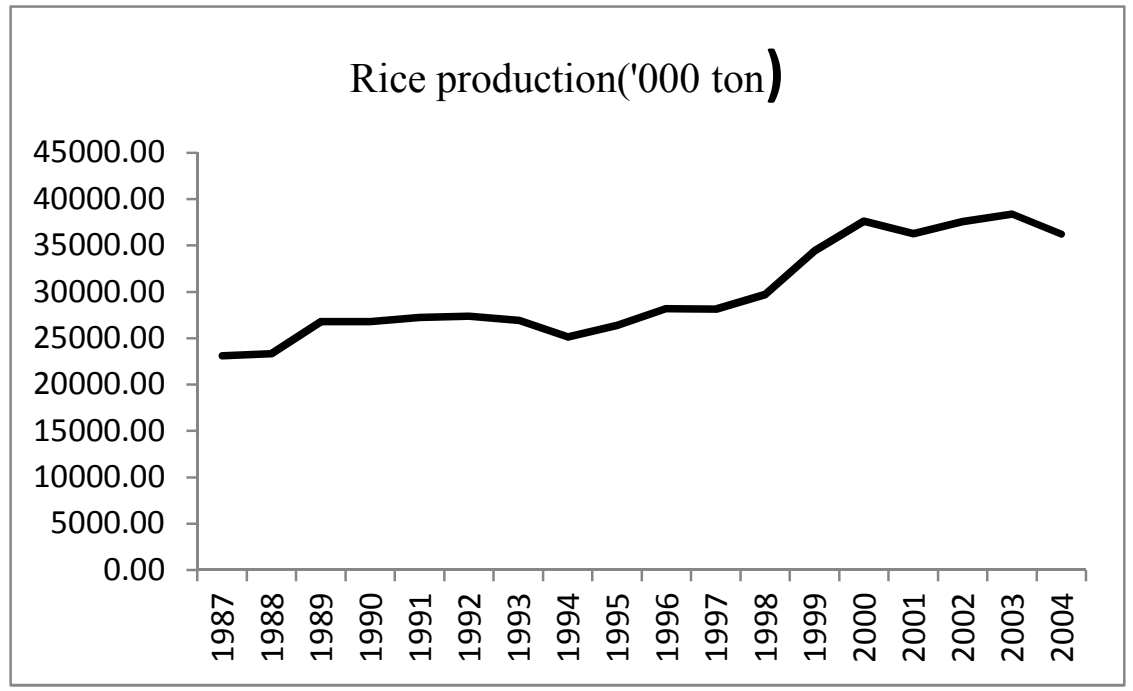

Source: FAOStat, 2008 